\section{The Joicey Collection of Lepidoptera}

RECENT remarks by a learned and very senior judge in the Chancery Division, who was engaged in the hearing of a summons concerning the disposal of the very valuable collection of Lepidoptera formed by the late $\mathrm{Mr}$. J. J. Joicey, serve to direct attention to the extraordinary lack of knowledge of natural history matters prevalent even amongst those whom one is accustomed to regard as amongst the best informed. The judge in this case is reported to have said that "He had never been to the Museum since he was taken there as a boy, much to his discomfort, and he always thought there was too much to see. If the collection went elsewhere it might be seen to better advantage." The museum concerned in the case was the Natural History Museum. Should the judge even now, how. ever, care to make amends, it is safe to say that he will be spared the horror of having to ' see ' the Joicey collection should it eventually, as is hoped, find its way to South Kensington; for, as is common know. ledge amongst naturalists, it is not the policy of the British Museum (Natural History) to display to the public collections of such great scientific value as this. Indeed, it would be impossible to do so in this case, for the 250,000 specimens involved would need a whole gallery (which is not available) for their accommodation. Surely it is time judges and others in high position ceased to express gratuitous opinions of the kind mentioned, which, in the long run, may do incalculable harm to the parties involved and, not least, to the respect in which the administrators of the law are normally held. Fortunately, in the case of $\mathrm{Mr}$. Joicey, the decision of the court, although it was not what it was hoped it would be, may still not prejudice the ultimate gift of his collection to the nation by the trustees of the estate of which it at present forms part.

\section{Waste: in Education and Chemistry}

Prof. Henry E. Armstrong is a provocative speaker whose observations in public are generally as pungent as they are pertinent; as a writer he excels in the art of garnishing a deal of common sense with a deal more of trenchant criticism. As a chemical criminologist Prof. Armstrong has no equal ; for many decades he seems to have watched his fellow chemists and educationists stray from the obvious path of rectitude and fall one by one into every kind of intellectual disgrace. Such unrivalled experience, together with the habit of fearless insistence on the importance of the most important things, serves to equip him admirably to play the double part of detective inspeetor and prison chaplain. On two occasions recently Prof. Armstrong has said much that was well worth saying, and has added a good deal that, in our opinion, is more likely to diminish than to enhance the brilliance of his analysis. The first address, delivered before the Imperial College Chemical Society in January last, was entitled "Waste Chemistry", and the second, delivered before the London and South-Eastern Counties Section of the Institute of Chemistry in February, was entitled "Shifting Sands". Prof. Armstrong detests waste--including most of the chemistry that is taught in schools and colleges. He deplores waste of effort in the perpetual killing of the slain under the disguise of new jargons. There is considerable point in his stricture (provided it be remem. bered that it is one thing to kill a dragon but quite another to keep it dead), whether or not this waste of opportunity is "owing to a cultivated and obtuse narrowness of vision "-and he can have full marks for the debating point. But this is not all; in addition to being wasters, we have no sense of proportion and no ability to work problems out to a logical end. Again, all this is probably true in some degree of most of us and in greater degree of some of us.

SrIm, the crimes alleged against the prisoner have not all been stated; according to Prof. Armstrong, our educational system is simply dishonest, being calculated to promote selfishness and to give employment to a maximum number of people, all bent, through their inability to think, on using their ignorance in misleading learners. A statement of this kind is purely provocative, and ought not to be made by Prof. Armstrong or anyone else. It ignores a vast amount of unselfish and earnest educational service, and despises the efforts of thousands of men and women of at least average ability and usually possess ing some sense of public duty and private responsibility. The educational army, nevertheless, will continue its march, whether or not Prof. Armstrong is the only one in step. To return to the addresses, and to discover in them things worth recording: Prof. Armstrong is undoubtedly right when he warns us that the nations cannot much longer allow the uncontrolled waste of natural resources to continue. Industry of every kind, he rightly says, must be controlled and organised with due reference to both raw materials and requirements, instead of being allowed to proceed, without thought of policy, merely as speculative, individual adventure. Emphasis is laid, too, on the relation of scientific discovery to the use of labour, and the attention of scientific people and employers of scientific people is directed to the need for discovering and directing labour-using rather than labour-saving occupations.

\section{Social Selection of Human Fertility}

Twe Herbert Spencer Lecture was delivered at Oxford by Dr. R. A. Fisher on June 8 on "The Social Selection of Human Fertility". After recalling the consistent efforts of Spencer towards the unification of the natural and social sciences, Dr. Fisher spoke of the hypothesis of complete determinism that has been held, as by Laplace, in the sphere of probability. From the course of physical investigation it might be plausibly conjectured that the mathematical formulæ, being often more accurate than the observa. tional results, must more nearly represent reality, and hence that any fortuitous element can be excluded from physical phenomena. Researches, however, into the nature of the ultimate particles of gases do nothing to strengthen the deterministic position. The only principle on which the behaviour of a system can be predieted is that its properties are the average of a large number of independent items of behaviour. Human societies may be large enough

$$
\text { No. } 3268 \text {, VoL. 129] }
$$


to show natural causation, where their constituents may be regarded as independently active. Limitations are imposed by organisation and by public opinion, but there are features of society which appear to be exempt from such limitations. These are (1) the hereditary endowment received by each generation, and (2) the individual reactions, though not the conditions, of what may be called the process of social promotion.

There is a presumption, Dr. Fisher said, that at the present day social promotion depends more on intellectual superiority and less on business aptitude than it did, say, a hundred years ago. Though no occupational class is strictly endogamous, the differences produced by selection for occupational status tend to be perpetuated. An unintentional feature that has arisen in our economic system is that the highest forms of ability are united with relative sterility, and vice versa. Whether a similar process was present in past civilisations it is for historians and archæologists to decide, but in regard to Great Britain " it is difficult to avoid the conclusion that a full half of whatever eugenic value this [fairly well-to-do] class contains may be counted as already lost". There is, Dr. Fisher concludes, no ground for fatalism ; but in considering the causes of an impending evil, we should as scientific workers distinguish between the inevitable and the avoidable, and as citizens we should in the latter case see to the application of the requisite control.

\section{Science and Philosophy}

IN his recent presidential address to the British Institute of Philosophy, under the title "Philosophy and the Ordinary Man", Sir Herbert Samuel pointed out that although all action and thought is the conscious or unconscious product of a philosophical attitude, the ordinary man takes little interest in philosophy, with which he thinks he has no coneern. In this respect philosophy contrasts strikingly with science, which arouses widespread interest. The reason is partly that expositors of science do not disdain to write in the vermacular, whereas many philosophers find it necessary to use a special terminology. It is chiefly, however, that science consists predominantly of a body of knowledge which commands common assent, whereas philosophy is largely an aggregate of individual systems of thought. Nevertheless, it has an important function to perform in constructing an authoritative code of morals for the guidance of those bewildered by the progress of science. It could best do this, said Sir Herbert, and at the same time command greater public interest, if it could be induced "to turn aside from a priori methods, to put no great faith in Logic as a guide, . . . and to press forward into the realms of metaphysics and ethics along the roads opened up by mathematics, physics, biology in general and psychology in particular, and by the social sciences".

The Principle of Causality

THE first principle which philosophy might receive, as established by science, is the principle of causality, which, in spite of recent attacks by some physicists, still reigns supreme. In support of this contention, Sir Herbert Samuel quoted a letter from Einstein and the published opinions of Planck. The principle of causality leads in philosophy straight to a theistic position; for since the universe is not self-explanatory, there must be "something else". We cannot, how. ever, at present fathom the nature of the Divine Mind. The principle of causality appears to deny human free-will, but although from a universal point of view this is so, events in the limited sphere of human action proceed as though our wills were free, and practical life must be conducted on that footing. A further application of the principle of causality in philosophy leads to a definition of the 'Good' as that which experience shows to promote well-being, rather than as an ideal standard of values. In the general adoption of the scientific method, philosophy will find its chief opportunity and its main strength.

\section{Harrison's Third Marine Timekeeper}

OF special interest among recent additions to the Science Museum collections is the third of the series of four chronometers designed and constructed by John Harrison between the years 1728 and 1759 ; this instrument has been lent by the Lords Commissioners of the Admiralty. The British Government had in 1714 offered an award of $£ 20,000$ for an accurate method of determining longitude at sea. It was realised that the problem could be solved by carrying on board ship a trustworthy timekeeper, and Harrison set himself the task of constructing such an instrument; after devoting practically his whole life to the work, he succeeded in winning the award with his fourth timekeeper. Harrison's No. 3 timekeeper is designed so as to be unaffected by the motion of a ship, while on account of the extensive use of friction wheels it requires no oiling ; it also embodies original and ingenious methods of compensation for variations of temperature and of arc. The chronometers Nos. 2 and 3 are now shown in motion side by side in the Science Museum; No. 4 is at the Royal Observatory, Greenwich.

\section{Zoological Collections of de Sélys}

MANY specialists on the systematics of the Vertebrata are under the mistaken impression that the famous collection made in the course of the nineteenth century by Michel Edmond de Sélys - Longchamps is either destroyed or lost. Happily this is not so. The collection was preserved in the Chateau de Longchamps près Waremme, Belgium, where it occupied the little museum which de Sélys built, but it was not readily accessible to specialists and was in the care of an old servitor. The fate of this collection, which is a veritable treasure-house for mammologists and ornithologists, has just been settled in a way which will give widespread pleasure. Barons Maurice, Raymond, and Edmond de Sélys-Longchamps, grandsons of the great zoologist, have given the whole collection to the nation, and it is being placed in the Royal Museum of Natural History at Brussels. Thus all de Sélys' zoological collections are brought together again, for in 1900 de Sélys bequeathed his important entomological collection to the Museum.

$$
\text { No. 3268, VoL. 129] }
$$

